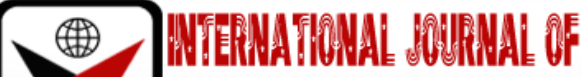

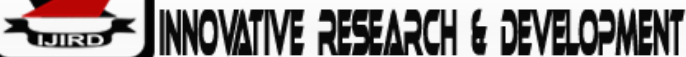

ISSN 2278-0211 (Online)

\section{Histological Morphology of Gill, Skin and Liver of Nile Tilapia Oreochromis Niloticus Fingerling Exposed to Jatropha Curcas (Linnaeus I779) Seed Powder}

\author{
Dr. Ibidun Comfort Adene \\ Senior Lecturer, Department of Fisheries and Aquaculture, \\ Adekunle Ajasin University, Akungba Akiko, Ondo State, Nigeria
}

\begin{abstract}
:
The effect of Jatropha curcas seed powderon the histopathology of selected organs of Oreochromis niloticus fingerlings was investigated. O. niloticusfingerlings of $6.5 \mathrm{~cm}-10 \mathrm{cmin}$ length and $14.7 \mathrm{~g}-18 \mathrm{gin}$ weight were exposed to different concentrations off.curcasseed powder at $133.3 \mathrm{mg} / \mathrm{l}, 200 \mathrm{mg} / \mathrm{l}, 266.7 \mathrm{mg} / \mathrm{l}, 333.3 \mathrm{mg} / \mathrm{land} 400 \mathrm{mg} / \mathrm{l}$. The acute toxicity of the toxicant to 0 . niloticusfingerlings was carried out using bioassay method under laboratory condition and the $96 \mathrm{~L} \mathrm{LC}_{50}$ was $439.23 \mathrm{mg} / \mathrm{l}$ with maximum admissible concentration of the toxicant to be $4.3923 \mathrm{mg} / \mathrm{l}-43.923 \mathrm{mg} / \mathrm{l}$ which is derived by multiplying the $96 \mathrm{~h} L C_{50}$ with an application factor of $0.01-0.1$. After $96 \mathrm{hr}$ of exposure, Histopathological changes of gill, liver and skin were observed. In the gill there was Degeneration of the gill arch,Lamellae are severely stunted,Shortened and High degeneration of gill arch, filament \& lamellae and Severe submucosal congestion, secondary lamellae are absent at the highest concentration. In the skin there wasNecrosis of the skinandHypertrophy, Necrosis and erosion of dermal cell. In the liver Disorientation of the liver parenchyma structures, Hyperplasia and disorientation of hepatic cells and marked sinusoidal congestion was observed. The pattern of response of $O$. niloticusfingerlings at the various concentration of J. curcasseed powder varied widely at the exposure duration. The observable effect of the toxicant on the examined organs could be could serve as a baseline information needed to develop models of J. curcas seed effects on ecological systems.
\end{abstract}

Keywords: Histopathology, oreochromis niloticus, jatropha curcas seed, gill, skin, and liver

\section{Introduction}

Fish farming or aquaculture has been described as the world's fastest growing food production system and has a lot been identified as a practical and promising approach to meeting the fish demand outside actual fishing (Abalaka and Auta, 2010). However, this sector is facing some challenges, thereby making fishing the only viable alternative where both conventional and unconventional methods are employed for the sole aim of obtaining fishes from the vast water bodies for human consumption. This includes the exploitation of synthetic compounds which bio-accumulates and persist in both target and non-target animals with the result of great effect on man and aquatic environment (Abalaka and Auta, 2010).

The main challenge facing aquatic environment is pollution and this has cause enormous havoc on the organisms in the environment especially their immune system, example of such an aquatic organism is fish which is continuously affected by periodic or unexpected changes of their environment. Adverse environmental situations may acutely or chronically stress the health of fish, altering some of their biochemical parameters and suppressing their innate and adaptive immune responses (Giron-peres et. al.,2007).

The health of fish can better be assessed by the histological changes of the organs and the effects of pollution on the biochemical parameters. The histological changes that occur in the organs of fish have been integrated with the impact of various stressors (microbial pathogens, toxic compounds, nutritional and adverse environmental conditions).

Jatropha curcas plant (Euphorbiaceae) is a multipurpose plant used for demarcations, construction of gardens, fence and traditional uses. It contains a variety of biologically active phytochemicals such as proteins, peptides and diterpenes exhibiting a spectrum of biological activities (Devappa et al., 2010, 2011).Despite all these attributes, the seeds contain toxic phytochemicals known as phorbol esters (PEs) (Haas et al., 2002; Rakshit et al., 2011).

Jatropha curcas L. is an oil-bearing shrub, widely distributed in Nigeria and many Latin American, Asian, and African countries (Gubitz et al., 1999). It is majorly cultivated in developing countries.

Recently, the non-edible Jatropha curcas has been hailed as one of the world's most sustainable biofuel crops. The Jatropha seed oil has gained tremendous interest as a feedstock for biodiesel production (Makkar and Becker, 2009; Devappa et al., 2010a).Among the different species of Jatropha, Jatropha curcas has a wide range of uses and promises various significant benefits to human and industry. Extracts from this species have been shown to have anti-tumor activity, the leaves can be used as a remedy for malaria and high fever (Gubitz et al., 1999; Henning, 1997) the seeds can be used in treatment of constipation and the sap was found effective in accelerating wound healing procedure (Gubitz et al., 1999). 
Species of the genes Jatropha are known to be very toxic. Several cases of J. curcas nut poisoning in humans after accidental consumption of seeds have been recorded. Symptoms such as giddiness, emesis and diarrhea have been reported (Makkar \& Becker, 1998).Jatropha is a drought resistant crop that has a life expectancy of up to 50 years (Koh et al., 2011).

Nile tilapia is a tropical species that prefers to live in shallow water. The lower and upper lethal temperatures for Nile tilapia are $11-12{ }^{\circ} \mathrm{C}$ and $42{ }^{\circ} \mathrm{C}$, respectively, while the preferred temperature ranges from 31 to $36^{\circ} \mathrm{C}$. Oreochromis niloticus is a relatively large cichlid fish, which is native to Africa from Egypt south to East and Central Africa and as far west as Gambia. It is also native to Israel, and numerous introduced populations exist outside its natural range (e.g. Brazil). According to Fagbenro (2002), it is presently farmed in the tropics, and sub-tropics of all continents, and occasionally where warm water is available, such as thermal effluent or geo-thermal spring.

During the raining season the rivers, sea, ponds and other aquatic environments are always filled with floods which in most cases comes with increase in volume and turbidity of water. The seeds of $J$. curcas comes along with the runoff from the gardens and farms into the rivers and ponds. In this case the seed can be swallowed by adult fish or crushed by some amphibians and crustaceans which assist in the release of the toxic substances such as the phorbol ester, the saponnis and the curcins that can be responsible for the toxification of the aquatic environment.

\section{Materials and Methods}

The experiment was conducted under standard static bioassay procedure (Reish and Oshida, 1987; American Public Health Association, 1987). Which involved carefully controlled environmental conditions as to define the response of the test fishes to J. curcas seed powder. The experiment was conducted at the Fish Farm (Obakekere) of the Federal University of Technology, Akure.

\subsection{Collection of Experimental Fishes}

Apparently healthy $O$. niloticus fingerlings $(6.5 \mathrm{~cm}-10 \mathrm{~cm}$, weighing $14.7 \mathrm{~g}-18 \mathrm{~g})$ were collected from Ondo State Agricultural Development Project (ADP) farm, Akure Ondo State, Nigeria, and acclimated for one week in the farm inside rectangular concrete tanks, $(75 \mathrm{~cm} \times 45 \mathrm{~cm} \times 45 \mathrm{~cm})$ container of 121.5 litres capacity, filled with 50litres unchlorinated well water. The fish were fed with pelleted fish diet containing $40 \%$ crude protein, during the acclimation period. Feeding was discontinued after 48 hours before the commencement of the experiment to minimize the production of waste in the test container.

\subsection{Preparation of Jatrophacurcas Seed Powder}

Large quantities of freshly mature seeds of J. curcas were collected from a private garden at No.12 Clerk Quarters, Owo, Nigeria. The seed powder was prepared according to the method described by Price (2000). The seeds were sundried at ambient temperature (25-28 $8^{\circ}$ over three days), seed coats and wings were manually removed. The white kernel was ground to fine powder, using the coffle mill attachment of a Moulinex domestic blender. The powder was kept in the freezer in an air tight cellophane bag for later use. The behaviour pattern and mortality of the test fishes in each tank was monitored and recorded every 15 minutes for the first hour, once every hour for the next three hours and every four hours, for the rest of the 24 hours, and once every $24 \mathrm{~h}$ until $96 \mathrm{~h}$. Dead fish were removed immediately with a scoop net.

\subsection{Toxicity Test}

\subsubsection{Range Finding Test}

Preliminary 24-hours range finding test was conducted for the experimental fishes following static bioassay procedures described by Parrish (1985) to determine the toxic range of J. curcas seeds to the experimental fishes. There were six treatments comprising three replicates, hence 36 tanks were used. A batch of ten of each of the experimental fishes were batch weighed and stocked into each tank $(75 \mathrm{~cm} \times 45 \mathrm{~cm} \times 45 \mathrm{~cm})$ filled with $30 \mathrm{~L}$ of unchlorinated well water. The seed powder was introduced into each tank at $400 \mathrm{mg} / \mathrm{l}, 466.67 \mathrm{mg} / \mathrm{l}, 533 \mathrm{mg} / \mathrm{l}, 600 \mathrm{mg} / \mathrm{l}$ and $666.67 \mathrm{mg} / \mathrm{l}$ with a control of $0 \mathrm{mg} / \mathrm{l}$. The behaviour and mortality of the test fish in each tank were monitored and recorded every 15 minutes for the first hour, once every hour for the next three hours and every four hours for the rest of the 24hours period.

\subsubsection{Definitive Test}

Based on the results from the range finding (Lethal toxicity) test described above, 96 hours definitive (sub-lethal toxicity) tests following static bioassay procedures described by Parrish (1985) was carried out. There were six treatments comprising threereplicates, hence 18 tanks were used. A batch of ten of each of the experimental fishes were batch weighed and stocked into each tank $(75 \mathrm{~cm} \times 45 \mathrm{~cm} \times 45 \mathrm{~cm})$ each filled with $30 \mathrm{~L}$ of unchlorinated well water. The seed powder was introduced into each tank at $133.3 \mathrm{mg} / \mathrm{l}, 200 \mathrm{mg} / \mathrm{l}, 266.7 \mathrm{mg} / \mathrm{l}, 333.3 \mathrm{mg} / \mathrm{land} 400 \mathrm{mg} / \mathrm{l}$. Test fish were not fed throughout the 96hours that the experiment lasted. Mortality of the test fish in each tank were monitored and recorded every 15 minutes for the first hour, once every hour for the next three hours, every four hours for the next 24 hours and every 24 hours for the remaining 96 hours. The inability of fish to respond to external stimuli was used as an index of death. Dead fish were removed immediately with a scoop net to avoid contamination due to rotting. Apart from monitoring and recording mortality, the fish behaviour such as erratic swimming, air gulping and loss of reflex were also monitored. 


\subsection{Histological Examination of Test Organs}

At the end of the experiment, one fish per treatment, that is, three fish per concentration were sampled after 96hours of exposure to J. curcas seed powder for histological analysis, the fish was anesthetized in aerated buffered tricaine methanesulfonate (MSS 222) to depress the CNS so as to reduce the impact of pain. The fish was sacrificed and dissected to remove the gill, liver and skin. The organs were fixed in 100\% formalin for three days after which the tissue was dehydrated in periodic acid Schiff's reagent (PAS) following the method of Hughes and Perry (1976). In graded levels of $50 \%, 70 \%, 90 \%$ and $100 \%$ alcohol for 3 days, to allow paraffin wax to penetrate the tissue during embedding.

The organs were then embedded in molten wax. Tissue were sectioned into thin sections (5-7 $\mu$ m), by means of a rotatory microtome and were dehydrated and stained with harris haematoxylin-eosin (H\&E) stain, Bancroft and Cook (1994), using a microtone and each section was cleared by placing in warm water (38ㄷ), where it was picked with clean slide and oven-dried at $58^{\circ} \mathrm{C}$ for 30 minutes to melt the wax. Slides containing sectioned materials/tissue was cleared using xylene and graded levels of 50\%, 70\%, 90\%, 95\% and 100\% alcohol for two minutes each.

The section was stained in haematoxyline eosin for ten minutes. The stained slide were observed under a light microscope at varying X100 magnification, sections were examined and photographed using an Olympus BH2 microscope fitted with photographic attachment (Olympus C35 AD4), a digital camera (Olympus C40 AB-4) and an automatic light exposure unit (Olympus PM CS5P).

\section{Result and Discussion}

The $96 \mathrm{~h} \mathrm{LC}_{50}$ obtained for the fingerlings of 0 . niloticus was $439.23 \mathrm{mg} / \mathrm{l}$.The maximum admissible concentration of toxicant to the fish was established to be $4.3923 \mathrm{mg} / \mathrm{l}-43.923 \mathrm{mg} / \mathrm{l}$ which is derived by multiplying the $96 \mathrm{~h}$ LC 50 with an application factor of $0.01-0.1$.

The histological changes observed in $O$. niloticus fingerlings exposed to $133.3,200,266.7,333.3,400 \mathrm{mg} / \mathrm{l}$ and $0 \mathrm{mg} / \mathrm{l}$ as control is presented in Table1 and Figures 1-3. Histological changes of gill, skin and liver was observed for all the treatments. Intensity of cell damage increased with increase in concentration.

\begin{tabular}{|c|c|c|c|}
\hline Concentration(Mg/L) & Gill & Skin & Liver \\
\hline CONTROL & No visible lesions & $\begin{array}{l}\text { Normal skin, No visible } \\
\text { lesion. }\end{array}$ & No lesions observed. \\
\hline 133.3 & No visible lesions & $\begin{array}{l}\text { Normal skin, No visible } \\
\text { lesion. }\end{array}$ & $\begin{array}{l}\text { Disorientation of the } \\
\text { liver parenchyma } \\
\text { structures. }\end{array}$ \\
\hline 200 & $\begin{array}{l}\text { Degeneration of the gill } \\
\text { arch }\end{array}$ & $\begin{array}{l}\text { Normal skin, No visible } \\
\text { lesion. }\end{array}$ & $\begin{array}{l}\text { Disorientation of the } \\
\text { liver parenchyma } \\
\text { structures. }\end{array}$ \\
\hline 266.7 & $\begin{array}{l}\text { Lamellae are severely } \\
\text { stunted }\end{array}$ & $\begin{array}{c}\text { Normal skin, No visible } \\
\text { lesion. }\end{array}$ & $\begin{array}{l}\text { Hyperplasia and } \\
\text { disorientation of } \\
\text { hepatic cells. }\end{array}$ \\
\hline 333.3 & $\begin{array}{c}\text { Shortened and High } \\
\text { degeneration of gill } \\
\text { arch, filament and } \\
\text { Lamellae. }\end{array}$ & Necrosis of the skin & $\begin{array}{l}\text { Marked sinusoidal } \\
\text { congestion }\end{array}$ \\
\hline 400 & $\begin{array}{l}\text { Severe submucosal } \\
\text { congestion, secondary } \\
\text { lamellae are absent. }\end{array}$ & $\begin{array}{l}\text { Hypertrophy, Necrosis } \\
\text { and erosion of dermal } \\
\text { cell of the skin. }\end{array}$ & $\begin{array}{l}\text { Severe degeneration of } \\
\text { hepatocyte }\end{array}$ \\
\hline
\end{tabular}

Table 1: Summary of Histological Changes Observed in O. Niloticus Finger Lings Exposed to Jatropha Curcas Seed Powder

Figures 1 to 6 Histological changes observed in the gill of 0 . niloticus fingerlings exposed to J.curcas seed powder for $96 \mathrm{~h}$.

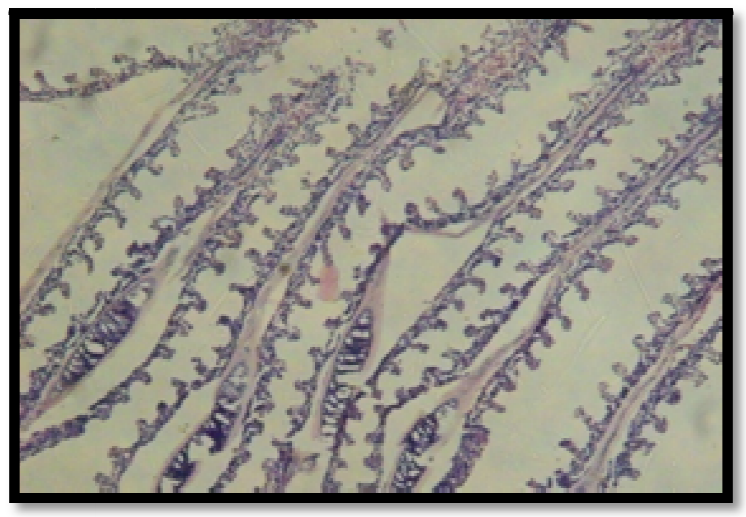

Figure 1: Gill of Fingerlings 0 . Niloticus inthe Control Tank with No Lesion (X100) 


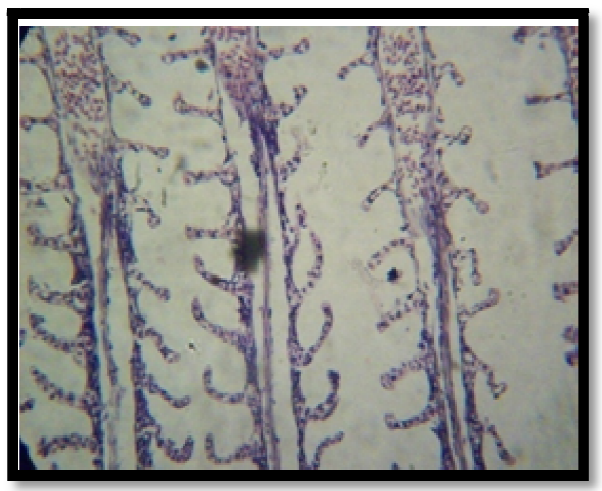

Figure 2: Gill of Fingerlings O. Niloticus Exposed to 133.3mg/L Showing No Lesion (X100)

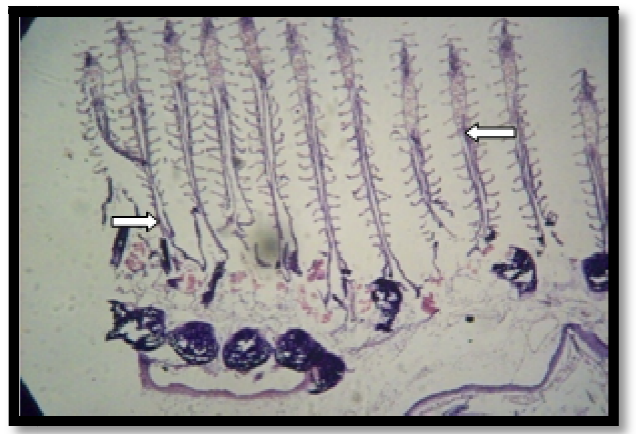

Figure 3: Gill of Fingerlings O. Niloticus Exposed to 200mg/L OfJ. Curcas Showing Degeneration on the Gill Arch. (X100)

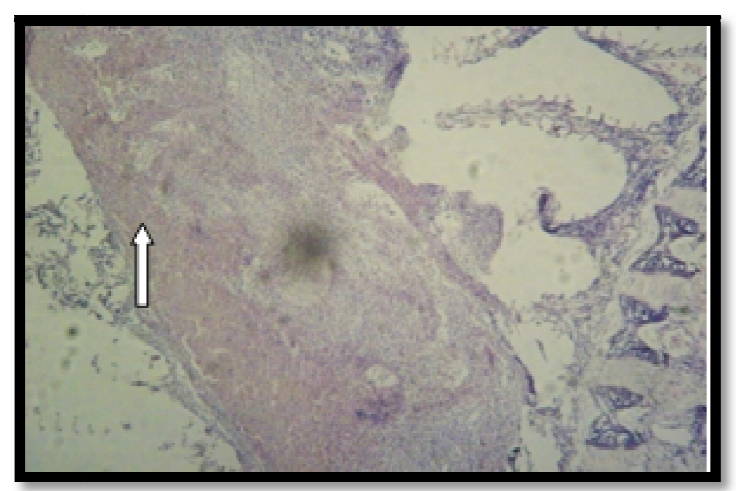

Figure 4: Gill Of Fingerlings O. Niloticus Exposed To $266.7 \mathrm{mg} / \mathrm{L}$ OfJ. Curcas Showing Severelystunted Lamellae(X100)

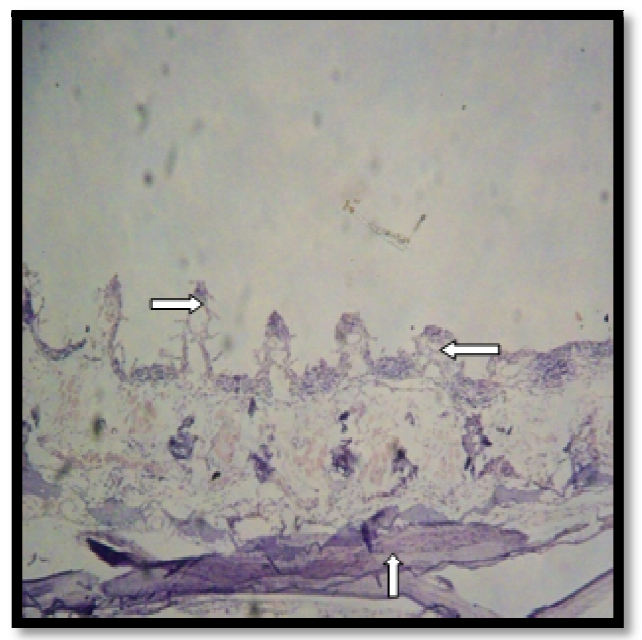

Figure5: Gill of Fingerlings O. Niloticus Exposed To 333.3mg/L ofJ. Curcas Showing Shortened and High Degeneration of Gill Arc, Filament and Lamellae. (X100) 


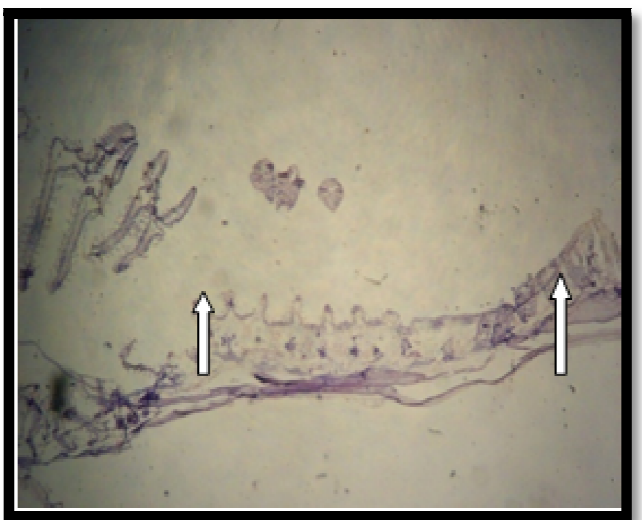

Figure 6: Gill of Fingerlings O. Niloticus Exposed To 400mg/L off. Curcas Showing

Severesubmucosal Congestion and Absence of Secondary Lamellae (X100)

Figures 7 to 12 Histological Changes Observed in The Skin Of O. Niloticus Fingerlings Exposed to Different Concentration of J.Curcas Seed Powder.

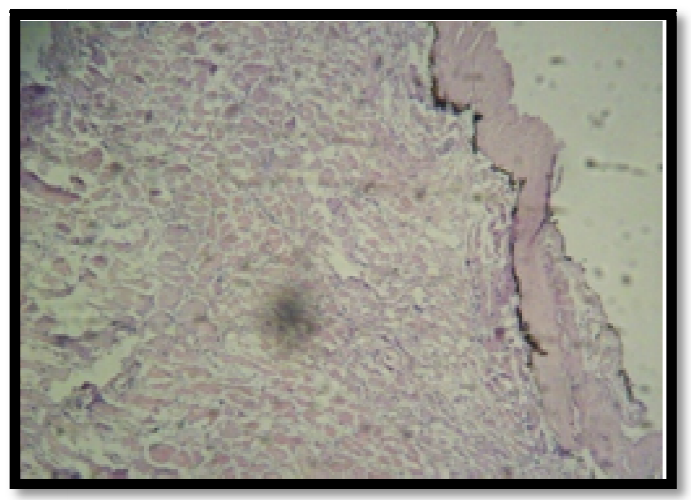

Figure7: Skin of Fingerlings O. Niloticus in the Control Tank with No Visible Lesion. (X100)

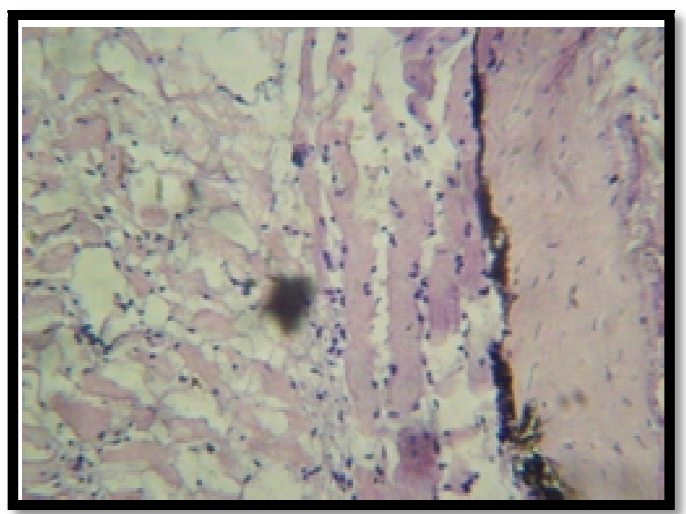

Figure8: Skin of Fingerlings O. Niloticus inthe Exposed To $133.3 \mathrm{mg} / \mathrm{L}$ ofJ. Curcas. No Visible Lesion inthe Skin. (X400

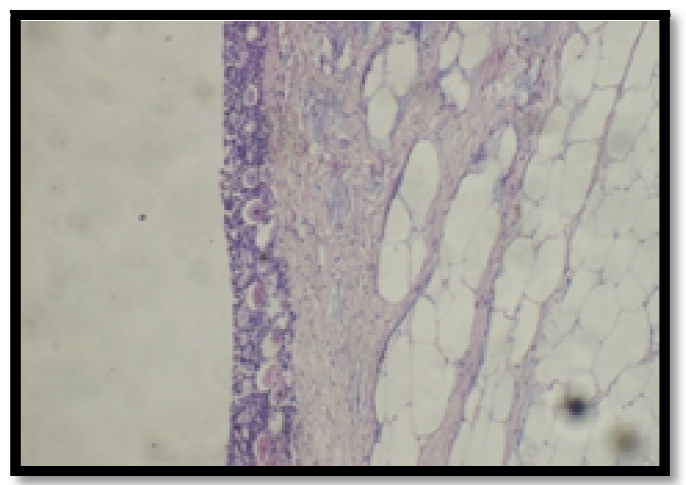

Figure9: Skin of Fingerlings O. Niloticusin the Exposed To 200mg/L ofJ. Curcas. No Visible Lesion inthe Skin. (X100) 


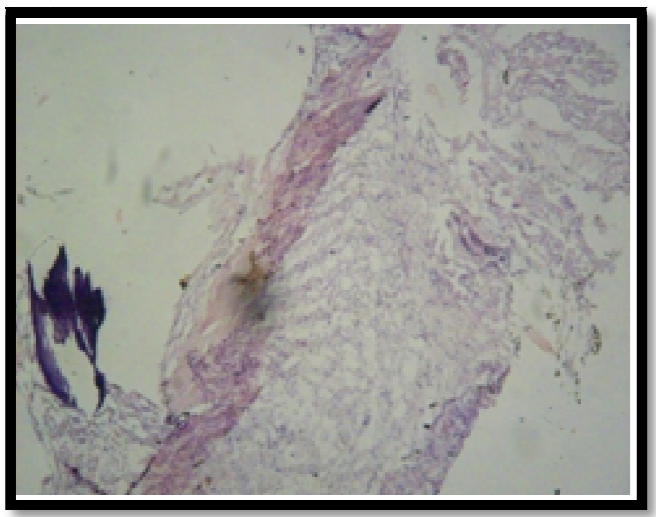

Figure 10: Skin of Fingerlings O. Niloticusin the Exposed To 266.7mg/L off. Curcas. No Visible Lesion inthe Skin (X100).

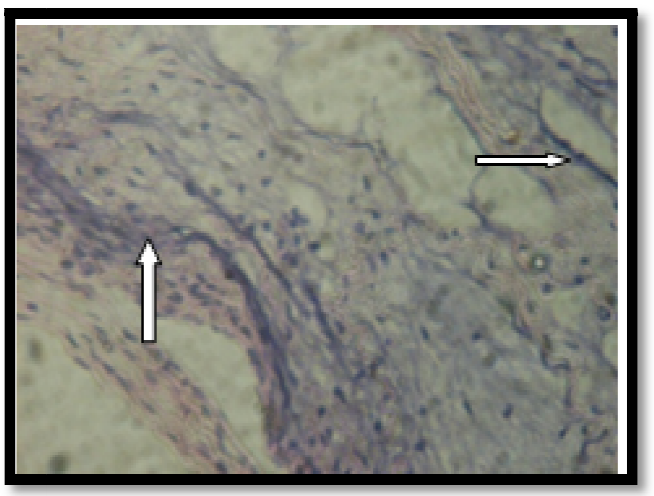

Figure11: Skin Of Fingerlings O. Niloticus In The Exposed To 333.3mg/L Of J. Curcas Showing Necrosis of The Skin

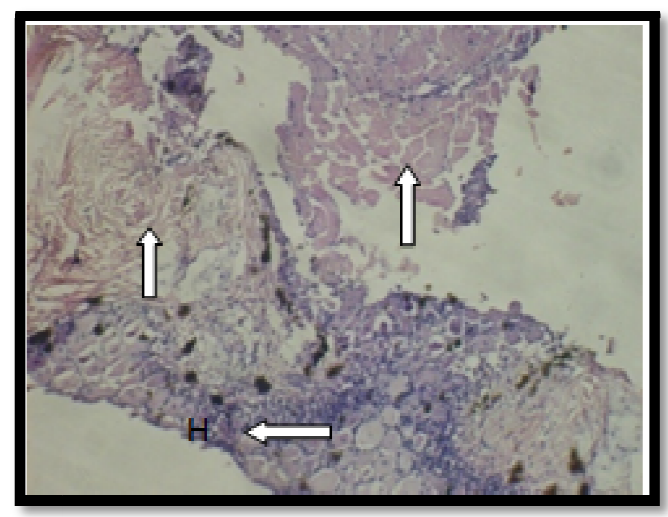

Figure12: Skin Of Fingerlings O. Niloticusin The Exposed To 400mg/L OfJ. Curcasshowing Hypertrophy, Necrosis And Erosion Of Dermal Cell of The Skin.

Figure13 to 18Histological Changes Observed In The Liver Of Fingerlings O. Niloticus Exposed To J.Curcas Seed Powder At $96 \mathrm{~h}$.

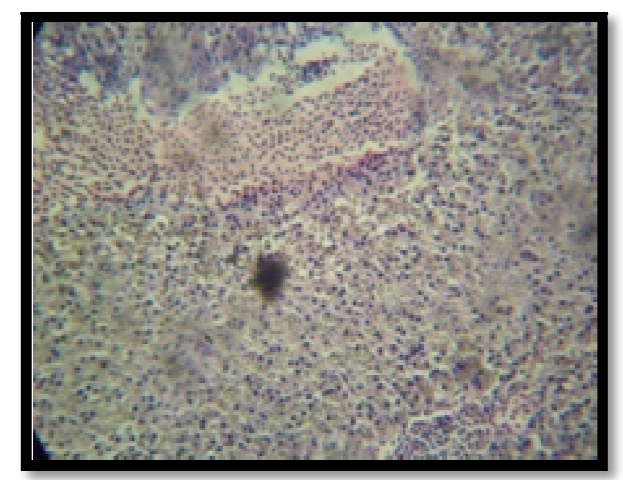

Figure13:Liver Of Fingerlings O. Niloticusin The Control Tankwith No Visible Lesion. (X100) 


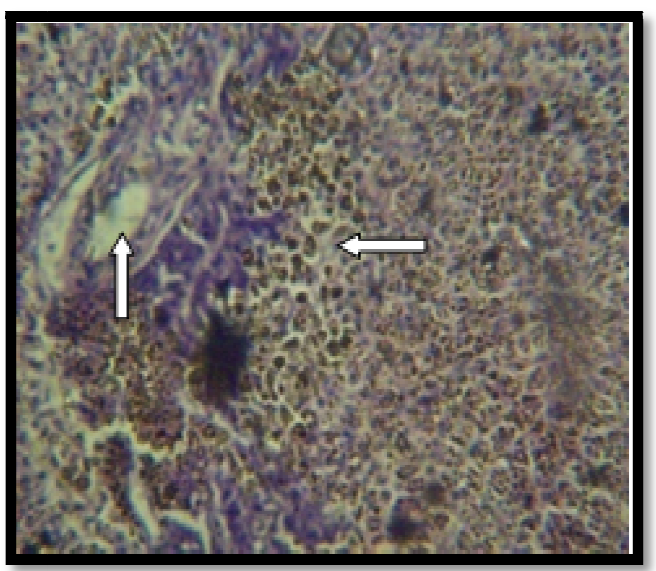

Figure14: Liver of Fingerlings O. Niloticusexposed to $133.3 \mathrm{mg} / \mathrm{L}$ OfJ. Curcas Showing Necrosis and Disorientation of the Liver Parenchyma Structures (X400)

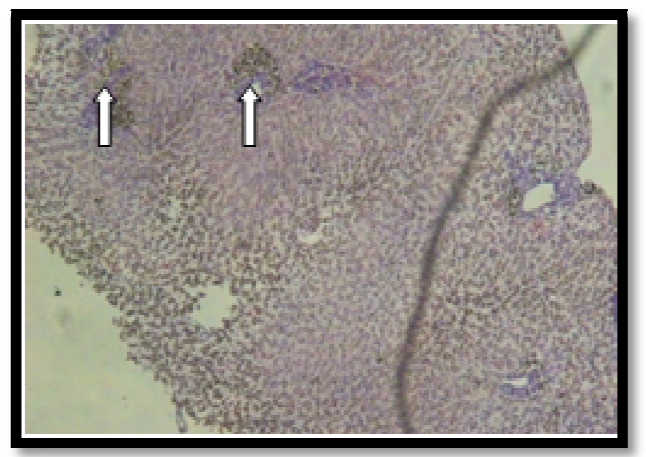

Figure 15 : Liver Of Fingerlings O. Niloticusexposed To 200mg/L OfJ. Curcas Showing Disorientation of the Liver Parenchyma Structures,(X100)

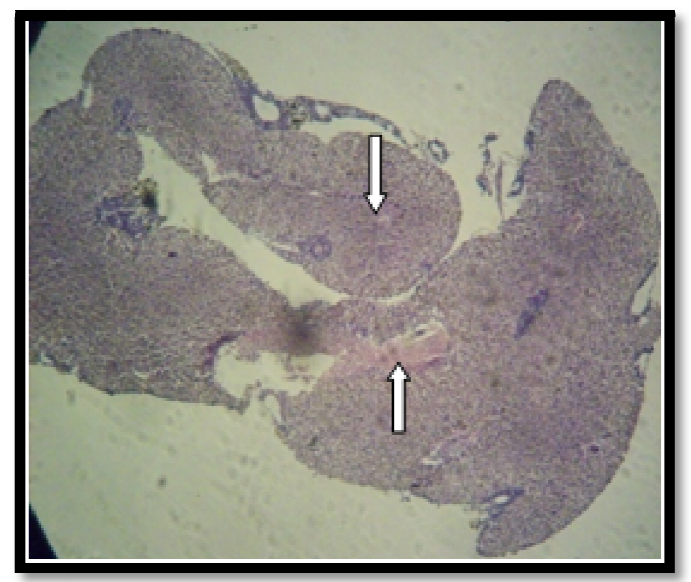

Figure16: Liver of Fingerlings O. Niloticus exposed to $266.7 \mathrm{mg} / \mathrm{L}$ Of J. Curcas Showing Hyperplasia and Disorientation of Hepatic Cells. (X100)

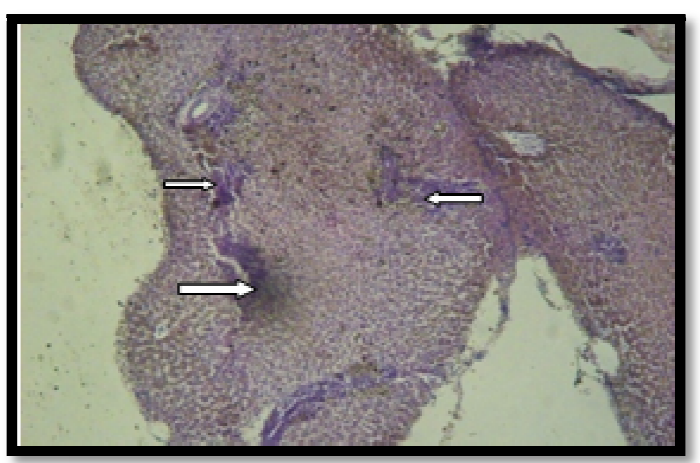

Figure 17: Liver Of Fingerlings O. Niloticusexposed To 333.3mg/L OfJ. Curcas Showing Marked Sinusoidal Congestion. (X100) 


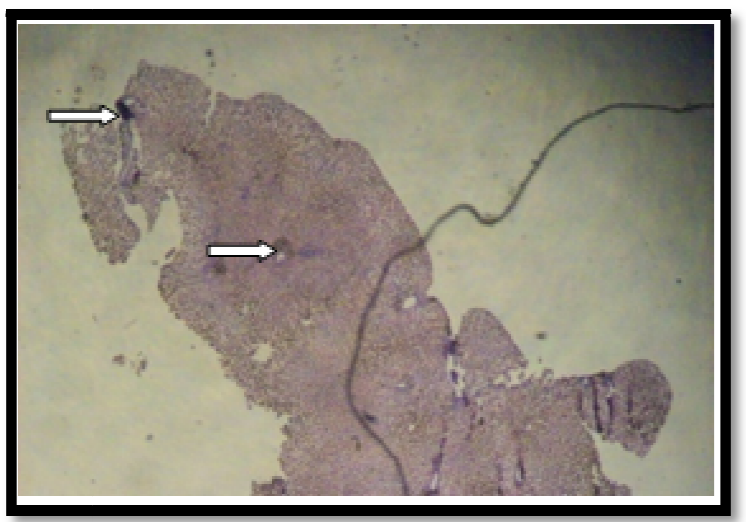

Figure18: Liver of Fingerlings 0 . Niloticusexposed to $400 \mathrm{mg} / \mathrm{L}$ Of J. Curcas Showing Severe Degeneration of Hepatocyte (X100)

\section{Discussion}

The values of the toxicity of $J$. curcas seed powder to the fingerlings of 0 . niloticus after $96 \mathrm{~h}$ of exposure reveal that the $96 \mathrm{~h} \mathrm{LC} \mathrm{LC}_{50}$ is $439.23 \mathrm{mg} / \mathrm{l}$ with maximum toxicant admissible concentrations of $4.3923-43.923 \mathrm{mg} / \mathrm{l}$ which is derived by multiplying the $96 \mathrm{~h} \mathrm{LC}_{50}$ with a constant value of $0.01-0.1$ according to Koesoemadinata (1980).

Ayotunde et al. (2011) reported lower concentration of the aqueous extract of Moringa olifera seed powder $96 \mathrm{~h}$ $\mathrm{LC}_{50}$ of $242 \mathrm{mg} / \mathrm{l}$ for $O$. niloticus fingerlings. Values of toxicity of $J$. curcas to $O$. niloticus is higher than the values obtained by Ayotunde and Ofem (2008) who reported $96 \mathrm{~h} \mathrm{LC} 50$ of $1.8 \mathrm{mg} / \mathrm{l}$, for 0 . niloticus exposed to the seed powder of Carica papaya. The value in this study is also higher than that of Ringworm plant Senna alata, used in poising water bodies for fish capture in Benue State of Nigeria, the $96 \mathrm{~h} \mathrm{LC} \mathrm{L}_{50}$ for juvenile 0 . niloticus was $13.93 \mathrm{mg} / \mathrm{l}$, Indicated that the extract causes sub acute effect. Ayoola (2011) obtained $\mathrm{LC}_{50}$ after $96 \mathrm{~h}$ of exposure for aqueous and ethanolic extracts of Ipomoea aquatica to be 2.659 and $0.196 \mathrm{~g} / \mathrm{L}$, respectively. Similar thing was observed by Agbon (2002); Ayotunde (2010ab); Ada et al. (2011), all these shows that J. curcas is less toxic to $O$. niloticus than all the toxicant used.

Histological examinations of $O$. niloticus gave significant indication of toxicity of J.curcas (Table1, Figures 1-3). The effects include gill alterations such as: Degeneration of the gill arc, Stunted lamellae, Degeneration of filament \& lamellae and congestion of submucosal of the gill which denotes gill functional disorders that may affect the fish physiology or cause death of the fish. Damages of the gills indicated impairment in gaseous exchange efficiency of the gills. This is similar to the observation of Ayotunde et al. (2011a) on toxicity of aqueous extract of Moringa Olifera on the fingerlings of 0 . niloticus. Histological evidence of the gill damaged caused by J. curcas toxicity was evident, resulting from malfunctioning of the gill. Francis et al. (2002) and Roy et al. (1990) reported that saponins an active component of J. curcas causes damage on respiratory epithelia of fish and that fish exhibit stress reactions to the presence of saponins in water.

The observations on the skin such as Necrosis, Hypertrophy and erosion of dermal cell could be as a result of the effect of the irritation due to direct contact with the toxicant and the curcanoleic acid contained in J. curcas which may promote skin cancer (Silitonga et al., 2011 and Osode et al., 2011). This agreed with the findings of Ayotunde et al. (2011a).

The intensity of cell damage increased with increasing concentration and time of exposure. The reactions on the skin could be as a result of paradoxical biological activities of phorbol ester a strong co- carcinogenic component of $J$. curcas seed.

The liver is an important centre of metabolism of various substances and supporting the stability of intracircumstances of organism, therefore the changes that occur in the liver would interfere with the normal metabolic function of the liver cells. Mortality may be as a result of the disorder of the liver. Changes that occur in the liver include: Disorientation of the liver parenchyma, hyperplasia \& disorientation of hepatic cell, sinusoidal congestion and degeneration of hepatocyte of the liver cells and necrosis. This agreed with Ayotunde et al. (2011a) which observed disorientation of the liver parenchyma structure, vacuole formation and shrinkages of cell in high concentration of $M$. oleifera treated O.niloticus fingerlings.

Degeneration and necrosis of liver hepatocytes may be attributed to the cumulative effect of $J$. curcas and the increase of their concentrations in the hepatic tissue. This result agreed with Forlin et al. (1986), who stated that the liver has important detoxical role on endogenous waste products as well as externally derived such as heavy metals. This is similar to what was observed by Ayoola (2011) when 0 . niloticus juveniles were exposed to aqueous and ethanolic extracts of Ipomoea aquatica leaf. The death of $O$. niloticus fingerlings could probably be as a result of all the malfunctions in the observed organs of the fish.

The observed effects of $J$. curcas seed powder on some of the organs of 0 . niloticusfingerlings fish had a positive correlation with exposure. Although the effects on the organs could be less when compared with other toxicant but the bioaccumulation effect on these organs of any exposed fish can be potentially hazardous especially the freshwater fish. Therefore, the results of the observations recorded in the present study provide baseline information needed to develop models of $J$. curcas seed effects on ecological systems. 


\section{References}

i. Abalaka, A. L and Auta J. (2010). Toxicity of Aqueous and Ethanol Extracts of Parkia biglobosa

ii. Pods on Clarias gariepinus Juveniles. Journal of Animal and Veterinary Advances, Vol. 9 Issue 6, 2010. Pg 10681072.

iii. Ada, F. B., Ndome, C. B., and Bayim P. B. (2011). Some haematological changes in Oreochomis niloticus exposed to Butachlor. Journal of Agriculture and Food Technology (JAFT)1(6):73-80.

iv. Agbon, A.O., Omoniyi, I.T, and Teko, A.A. (2002). Acute toxicity of Tobacco Nicotianatobaccum leaf dust on Oreochromis niloticus and haematological changes resulting from sub- lethal exposure. Journal of Aquatic Sciences. Vol. 17, No1

v. APHA, (1987). Standard method for examination of wastewater and water (17th ed. Washington D. C) 8910 Pp.

vi. Ayoola S. $O$ (2011).Histopathology of Nile Tilapia (Oreochromis niloticus) juveniles exposed to aqueous and ethanolic extracts ofIpomoea aquatica leaf.International Journal of Fisheries and Aquaculture Vol. 3(14), pp. 244-257.

vii. Ayotunde, E.O. and B.O. Ofem, (2008): Acute and chronic toxicity of pawpaw (Carica papaya) seed powder to adult Nile tilapia (Oreochromis niloticus Linne 1757).African Journal of Biotechnology, 7: 2267-2274.

viii. Ayotunde, E.O., B.O. Offem, I.B. Okey, G.U. Ikpi, S.N. Ochang, N.E. Agbam and D.O. Omini, (2010): Toxicity of pawpaw (Carica papaya) seed powder to sharptoothcatfish Clarias gariepinus fingerlings and effects on haematological parameters. International Journal of Fisheries and Aquaculture, 2: 71-78.

ix. Ayotunde, E.O, Fagbenro, O.A and Adebayo, O.T (2011a): Histological Changes in Oreochromis niloticus (Linnaeus I779) Exposed to Aqueous Extract of Moringa oleifera

x. Seeds Powder. Turkish Journal of Fisheries and Aquatic Sciences 11: 37-43.

xi. Ayotunde, E.O., Offem, B.O and Bekeh, A.F. (2011b): Toxicity of Carica papaya Linn: Haematological and Piscicidal Effect on adult Catfish (Clarias gariepinus)Journal of Fisheries and Aquatic Science, 6: 291-308.

xii. Bancroft, J.D and Cook, H.C (1994) Manual of histological techniques and their diagnostic application. Churchil Livingstone, London. Pp.289-305.

xiii. Devappa, R.K., Makkar, H.P.S and Becker, K.(2010a): Quality of biodiesel prepared from phorbol Ester extracted Jatropha curcas oil. J.Am.OilChem.Soc.87,697-704.

xiv. Devappa, R.K., Makkar, H.P.S and Becker, K., (2010b): Nutritional, biochemical, and pharmaceutical Potential of proteins and peptides from Jatropha: review. Journal of Agriculture and Food Chemistry. 58,6543-6555.

xv. Devappa, R.K., Rajesh, S.K., Kumar V., Makkar, H. P.S. and Becker, K. (2011): Activities of Jatropha curcas phorbol esters in various bioassays. Ecotoxicol. Environ. Saf.doi:10.1016/j.ecoenv.2011.11.002.

xvi. Fagbenro, O.A (2002): Tilapia: Fish for thought. Inaugural lecture series 32. Delivered at Federal University of Technology, Akure. Pp.77.

xvii. Forlin, L., Anderson, T., Haux, C., Olsson, P.E and Larsson, A (1986): Physiological methods in fish toxicology, laboratory and field studies.

xviii. Francis, G., Kerem, Z., Makkar, H.P. S and Becker, K (2002): The biological action of saponins in animal systems: a review. British Journal of Nutrition Vol.88, 587-605.

xix. Giro'n-Pe'rezM.I., Santene, A., Gonzalez-jaime, F., Casas-solis, J.,Hernandez-coronado, M., Peregrina-sandoval, J., Takemura A. and Zaitseva, G. (2007): Immunotoxicity and hepatic function evaluation in Nile tilapia cells (Oreochromis niloticus) exposed to diazinon. In fish and shellfish immunology,23 (2007) 760-769.

xx. Gubitz, G.M., Mittelbach, M., Trabi, M., (1999): Exploitation of the tropical oil seed plant Jatropha curcas L. Bioresour. Technol. 67, 73-82.

xxi. Haas, W., Strerk, H and Mittelbach, M. (2002): Novel12-deoxy-16-hydroxyphorbol diesters isolates from the seed oil of Jatropha curcas. J.Nat.Prod.65, 1434-1440.

xxii. Henning, R., (1997): Fuel Production Improves Food Production: The Jatropha Project in Mali.Proceedings from the symposium Jatropha 97, Managua, Nicaragua

xxiii. Hughes, G. M., and Perry, S. F (1976): Morphometric study of trout gills: A light microscopic method for the evaluation of pollutant action. J. Exp. Bio., 63: 447-460

xxiv. Koesomadinata, S. (1980): Pesticides as a major constraint to integrated agricultural farming system P. $45-51$. In Pullin et al (eds) Integrated agriculture - aquaculturefarming system. ICLRM conference proceeding.

xxv. Koh, M.Y., Ghazi, T.I.M. (2011): A review of biodiesel production from Jatropha curcas L.oil. Renewable and Sustainable Energy Reviews 2011;15(5):2240-51.

xxvi. Makkar, H.P.S., Becker, K., Schmook, B., (1998): Edible provenances of Jatropha curcas from Quintana Roo state of Mexico and effect of roasting on antinutrient and toxicfactors in seeds. Plant Foods Human. Nutrition. 52, 31-36.

xxvii. Makkar, H.P.S., Becker, K., (2009): Jatropha curcas, a promising crop for the generation of biodiesel and valueadded coproducts. European Journal of Lipid Science Technology. 111,773-787.

xxviii. Oshode, O. A., Bakare, A. A., Adeogun, A. O., Efuntoye M. O. and Sowunmi, A. A.(2008): Ecotoxicological Assessment Using Clarias gariepinus and Microbial

xxix. Characterization of Leachate from Municipal Solid Waste Landfill. International Journal of Environmental Research, Vol. 2, No. 4, Autumn, 2008, pp. 391-400.

xxx. Price, M.L. (2000): The Moringa tree. ECHO Dev. Note. U.S.A. RAHMAN, M. N., Holssain, Z., Mollah, M. F.A. \& Ahmed. 
xxxi. Rakshit K., Sanjay, K. R, Vikas Kumar, HarinderP.S. Makkarand KlausBecker (2011): Activities of Jatropha curcas phorbol esters in various bioassays. Ecotoxicology and Environmental Safety.

xxxii. Reish, D. J. and Oshida, P. S. (1986): Manual of methods in aquatic environment research. Part 10. Short term static bioassays. FAO Fish Tech. Pap. (247), 62.

xxxiii. Roy, P.K.,Munshi, J. D and Dutta, H.M (1990): Effect of saponinextracts on morpho-history and respiratory physiology of anair breathing fish, Heteropneustes fossilis(Bloch). Journal of Freshwater Biology 2, 135-145.

xxxiv. Silitonga, A. S., Atabani, A.E., Mahlia,T.M.I., Masjuki, H.H.,Badruddin, I.A and Mekhilef, S.

xxxv. (2011): A review on prospect of Jatropha curcas for biodiesel in Indonesia.Renewable and Sustainable Energy Reviews 15 (2011) 3733-3756. 